\title{
Vaults, roof truss and walls interaction issue in monumental masonry structures
}

\author{
Marcin Szkobodziński ${ }^{1,}{ }^{*}$, Czesław Miedziałowski ${ }^{2}$ \\ ${ }^{1} \mathrm{MSc}$, Department of Geotechnics and Structural Mechanics, Bialystok University of Technology, \\ Poland \\ ${ }^{2}$ Professor, Dsc, PhD, Department of Geotechnics and Structural Mechanics, Bialystok University of \\ Technology, Poland
}

\begin{abstract}
The paper discusses the subject of interaction between a roof truss, vaults and load-bearing walls in a masonry monumental structure. The static structural analysis of the Assumption of the Blessed Virgin Mary Basilica in Bialystok, as an example of Polish neogothic architecture from the turn of the 19th and 20th centuries has been carried out. The building consists of a three-aisled masonry walls system, which in cooperation with cross-ribbed vaults and a timber roof truss determine the spatial rigidity of the structure. Lack of concrete ring-beams and horizontal oriented ceiling slabs cause global stiffness reduction to the horizontal loads. In the past, it could have been one of the main reason for the appearance of cracks in the structure. The basic aspect having a real influence on building global behaviour is interaction of load-bearing structural parts. This structure was subjected to the static analysis with an investigation about the influence of interaction between the roof truss, vaults and walls. The values of horizontal displacements of walls were compared as a result of wind pressure acting on the structure. Numerical calculations were carried out using finite element method.
\end{abstract}

\section{Introduction}

Static analysis of monumental masonry structures is complicated and difficult to compute, which mainly results from the need to obtain the distribution of internal force values, as real as possible, in structural elements. Results are used during periodic technical expertise and at an early stage they allow predicting building damage sources. Locations of sensitive places in a structure are especially important, because their characteristic feature is the creation of local stress concentration [1-3]. Static analyses are also used to propose eventual reinforcements and determine their influence on structure behavior [4, 5]. The static analysis method of monumental masonry buildings in most cases goes beyond standard simplified approaches. Striving for the most credible modeling of the actual static work of a structure requires a consideration of cooperating elements, which are connected with the analyzed part. It results from the necessity of adopting, dependent on structural stiffness, correct loads distribution and consider redistribution of stresses [6]. Plane schemes are

* Corresponding author: m.szkobodzinski@doktoranci.pb.edu.pl 
replaced by spatial systems. The correctness of structure complex modeling is discussed [3, 7], stressing the usefulness of using simplified methods, which in this case seem to fulfill only the verification function of obtained results. One of the main methods used in the analyzing process of historic masonry buildings in a complex manner is the finite element method, which is shown in numerous publications [1, 8-13].

The use of spatial schemes in static analysis is also associated with, despite a number of advantages, significant disadvantages such as the effort required in model generation and the extended time needed to solve the computational problem [1]. Time of geometric modeling for conducted research is dependent on complexity of the structural system, which is subjected to calculations. This is especially the case when it concerns historic buildings, which have often representative functions and a complex shape.
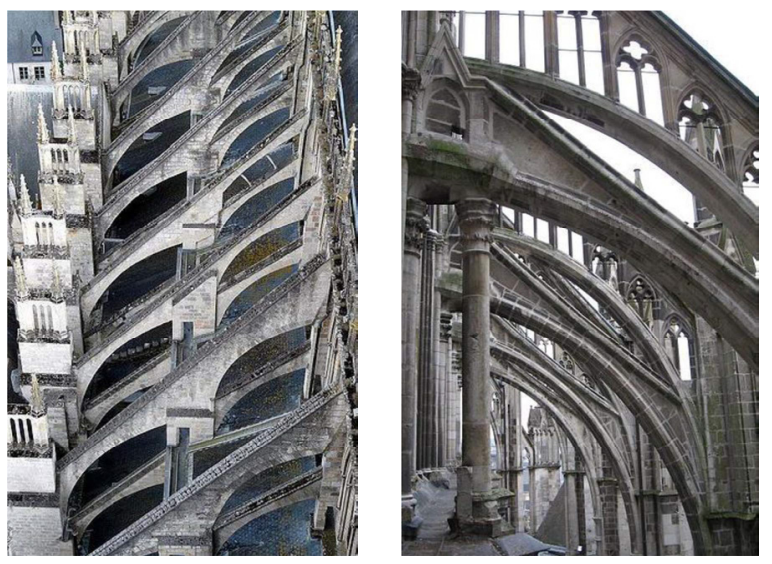

Fig. 1. Complexity of building shape caused by multi-storey flying buttress system [23, 24].

Complexity of structure results among other things from curved load bearing elements such as vaults, a flying buttress system or arched lintels and beams. In the case of sacral buildings, a multi-nave structural system has a huge influence, which is associated with the occurrence of a multi-span and multi-storey flying buttress system (Fig. 1).

Time consumption calculations of analyzed buildings in a complex manner is an effect of model size - there is a number of finite elements, which is needed to obtain appropriate, accurate results. The solution of the issue characterized by a large global stiffness matrix entails having a greater time consumption of calculations and necessitates having computer equipment with an above average computing power.

Structural systems occurring in monumental masonry structures are usually deprived of rigid horizontal ceilings, which allow loads distribution on the walls to be uniform. The specificity of historic masonry buildings is emphasized in [3, 7] publications, stressing that such buildings are sensitive to damage due to their characteristic structural elements. In modern apartment buildings, a function of the above mentioned horizontal plates are realized by concrete ceilings, which through concrete ring-beams ensure load transferring and guarantee good spatial stiffness of structure. Thanks to the mutual cooperation, horizontal loads from the wind acting on a structure or seismic activity can be uniformly distributed on all load-bearing walls and limit horizontal and torsional displacements.

Vaults appearing in monumental buildings are the equivalent of the ceiling in apartment buildings, but due to the curved shape they have reduced flexural stiffness. It has an influence on the global behaviour of a structure, because increased susceptibility of vaults reduces spatial stiffness of a building and endangers a structure to damage as a effect of excessive displacements. Also a precise definition of the form of connections is a significant issue, which despite the local importance can determine the behaviour of the entire vaults [13]. 
The roof truss is also involved in the static work of whole building and connects load bearing walls in the upper part. The possibility of horizontal loads transferring between walls as in the case of vaults may raise doubts, because it results in a large extent from roof truss stiffness and the way it is supported by walls.

Degree of cooperation between the roof truss, vaults and walls is an important issue. In this article on example of a monumental masonry sacral building, a variable numerical analysis of spatial stiffness was carried out comparing horizontal displacements of load bearing walls.

\section{Description of analyzed monumental building}

The analyzed monumental building was the Assumption of the Blessed Virgin Mary Church in Bialystok. This building was constructed at the turn of the $19^{\text {th }}$ and $20^{\text {th }}$ centuries in the neogothic architectural style in the Vistula-Baltic variant. The popular at that time architectural style of temples in Poland was characterized by features referring to the classic gothic style - an ogival building shape and despite the considerable size, slenderness and visual lightness was visible from the observer's point of view (Fig. 2).

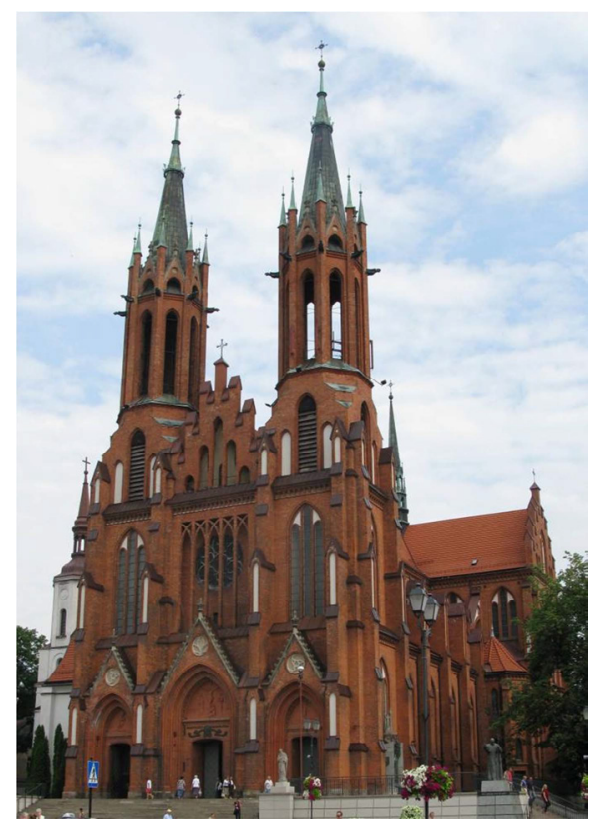

Fig. 2. The Assumption of the Blessed Virgin Mary Basilica in Bialystok [14].

The temple has, reffering to the Latin crucifix horizontal projection form consisting of a three-aisled main system, a three-sided presbytery and transversely located nave. The church building has a total length of $68 \mathrm{~m}$ and width in the place of transept of approximately $35 \mathrm{~m}$. The three-aisled system in the middle part of the structure consists of two lower side naves with a width of $6.25 \mathrm{~m}$ and a 10 -meter higher nave. The total height of the church building including two front towers is approximately $72 \mathrm{~m}$.

External walls have reinforcements in the form of pilasters and a flying buttress system, which are additional supports for the walls of the main nave transferring wind load and thrust forces from vaults to the lower structural parts and foundations. From the side of the existing white church, due to the fact that it's an adjacent building, there aren't any arches in the flying buttress system. 
Interior of the temple is limited from the top by vaults supported by columns and external walls, which in the main nave, presbytery and transversal nave are located at an altitude of $23 \mathrm{~m}$. Naves are covered with the cross vaults, except for the location over the crossing of main and transversal naves, where the lierne vault was constructed. The crystal vault is constructed over the chorus.

A queen-post timber roof structure is located above the main vaults, while above the side vaults a purlin-knee walls roof with an inclined knee wall is supported by masonry walls. The roof inclination angle is 44 and 60 degrees. In the place of the main and transversal naves' connection and near the towers, the roof truss has valleys. An additional slender bell gable is located above the lierne vault.

The facade of the church is decorated with numerous ornaments typical for gothic style, such as: blendes, pinnacles, graded pilasters, wimpergs, gargoyles, and an interior with finials and specific heads.

The main structural material of vaults and walls is masonry made of ordinary or profiled ceramic bricks and lime mortar $[14,15]$.

During the time of over 110 years of exploitation, the structure was exposed to many destructive factors. Part of them resulted from the poor quality embedded in the structure's materials, but causing the biggest cracks, factors according to $[14,16]$ should be sought among exceptional loads that the building was exposed during world war II and immediately after it.

It could have been a series of vibrations caused by explosions during the demolition of the city. That could be the main reason of the formation of cracks. After the war, regular technical condition inspections were conducted. Opinions received from inspections led to further repairs, for example replacement of bricks and decorative elements, flying buttress arches and the repair of towers. Technical condition inspections confirmed that poor quality materials were used and this led to faster corrosion processes.

\section{Basic assumptions of numerical analysis}

In order to define the influence of the roof truss, vaults and walls interaction, a static analysis of horizontal displacements as a structure global stiffness determinant was carried out. Numerical calculations of church building main nave system were carried out on a previously prepared model using the finite element method (Fig. 3). The masonry part of the structure was made of higher order 3D 10-nodes solid elements having three degrees of freedom per node. Maximum finite elements size was $70 \mathrm{~cm}$. Boundary conditions resulting from the walls of the transverse nave and tower part of the structure were defined by blocking displacements in the direction of the acting wind load.

In the calculations according to the recommendations [1], elements made of masonry were modeled as a macro-model $[17,18]$. The assumptions about material homogeneity and material properties defined according to the [19] standard were made. Values of Young's modulus E=1.32 GPa and Poisson's ration v=0.2 for masonry were defined. Structural timber elements of the roof truss located above main and side naves were described by material characterized by Young's modulus $\mathrm{E}_{\mathrm{T}}=11 \mathrm{GPa}$ and Poisson's ratio $\mathrm{v}_{\mathrm{T}}=0.05$.

The temple building has an atypical shape, which mainly results from the perpendicular orientation of the main nave to transversal nave, characteristic flying buttress system and the two front towers crowning the entrance. Therefore, definition of the most reliable load distribution is significantly impeded. The current standard [20] in the case of an atypical building shape allows one to determine the wind load acting on a structure in a different way than the mathematical model included in the standard, based on recognized and reliable sources. In most cases, a wind-tunnel test on a specially prepared laboratory model of the building's shape are carried out. Examples of such an analysis can be found in [21, 22]. 
It is the most accurate solution, but it requires high financial outlays for the research. In the other cases, adaptation of schemes contained in the standard [20] is also possible. Combining successive simple schemes, whose drag coefficient is given in the standard [20] allows obtaining values of wind load in buildings characterized by sometimes quite high complexity. However, this approach in relation to the wind tunnel tests is associated with greater error both in terms of underestimation as well as overestimation.

In the numerical research a wind load was assumed according to the current standard [20], whose values are shown in Table 1. Due to the lateral loads structure stiffness analysis, in addition to the wind load, only dead load resulting from the building's own weight was taken into account. The masonry weight was $1800 \mathrm{~kg} / \mathrm{m}^{3}$, while the timber weight was $420 \mathrm{~kg} / \mathrm{m}^{3}$.

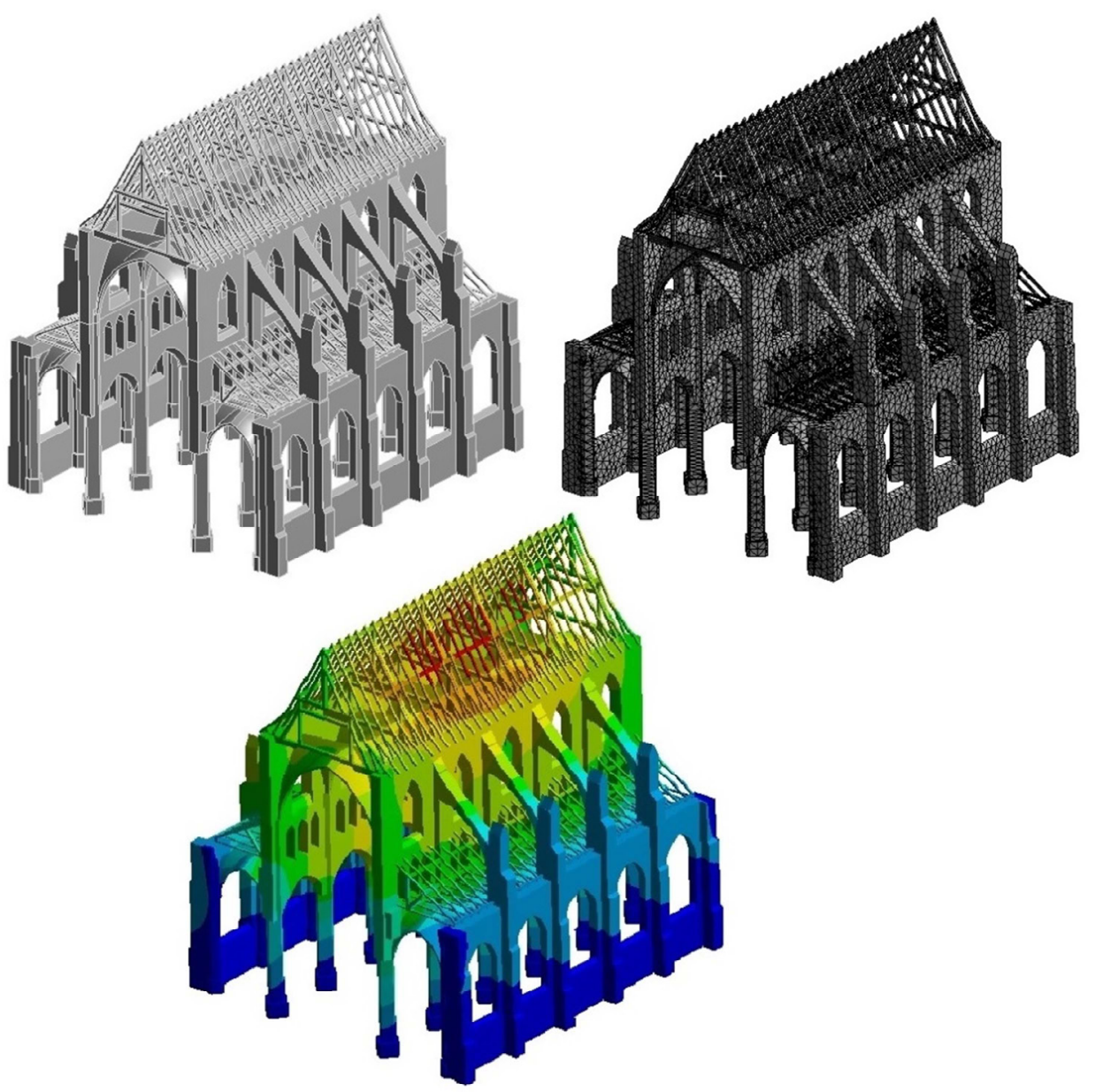

Fig. 3. Model of analysed monumental sacral building.

Four variants of the church building with different types of roof truss and vaults interaction were analyzed:

- Variant 1 - structure of masonry walls with roof truss and main nave vaults interaction,

- Variant 2 - structure of masonry walls with roof truss interaction,

- Variant 3 - structure of masonry walls with main nave vaults interaction,

- Variant 4 - structure of masonry walls without roof truss and vaults interaction. 
In the carried out numerical analysis, the values of horizontal displacements of the windward upper edge masonry wall were compared. The static linear analysis equilibrium equations are described by formula:

$$
[\mathbf{K}]^{-1}\{\mathbf{F}\}=\{\mathbf{u}\}
$$

where:

$[\mathbf{K}]-$ global stiffness matrix

$\{\mathbf{F}\}$ - load vector

$\{\mathbf{u}\}$ - displacement vector

The measuring points are shown in Fig. 4. Displacements analysis allows the determination of spatial stiffness changes under the influence of roof truss and the vaults' elimination from the static work of structure.

Table 1. Values of wind load used in analysis.

\begin{tabular}{|c|c|c|c|c|c|c|}
\hline Area name & D & E & G & H & I & J \\
\hline Wind load value $\left[\mathbf{k N} / \mathbf{m}^{2}\right]$ & 0.622 & -0.454 & 0.545 & 0.545 & -0.156 & -0.233 \\
\hline
\end{tabular}

In variants 3 and 4, loads acting on the roof, due to the lack of roof truss structure, were collected manually from the windward and leeward roof area and then applied to the upper edge of the main nave load-bearing walls in the form of a linear load.

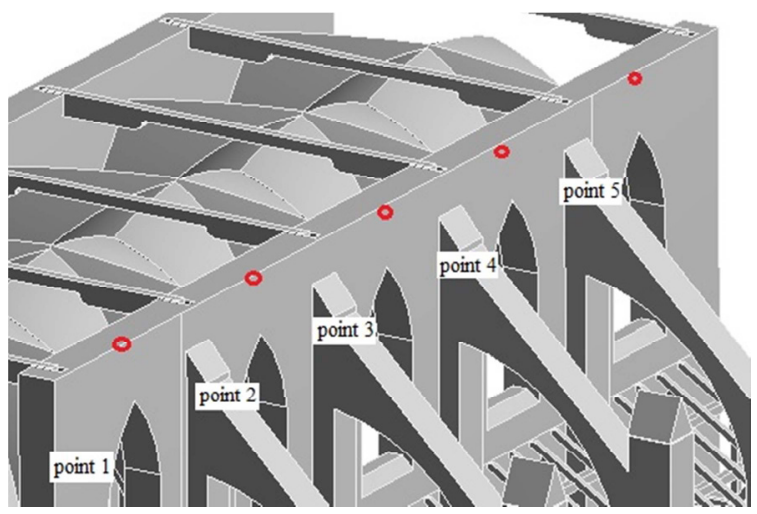

Fig. 4. Location of measuring points.

\section{Results and conclusions}

Based on the static linear numerical analysis carried out for each of the proposed variants, the values of horizontal displacements in the perpendicular area located at the face of the external walls at five measuring points were obtained. The results are shown in Table 2 and in graph (Fig. 5).

In variant number 1 the roof truss and vaults cooperated with the walls. The lowest displacements reaching a maximum of approximately $6.1 \mathrm{~mm}$ were obtained at all measuring points. After removing the vaults (Variant 2) in relation to variant number 1, displacements significantly increased by nearly $71 \%$ in the middle of the wall span. Obtained in this way, results confirmed how important cooperation of the vaults is. In the next analysis (Variant 3), where the roof truss was eliminated from the static work of the structure, a displacement increase by approximately $16 \%$ was observed. This value corresponded to about a $7.1 \mathrm{~mm}$ displacement in the middle of the wall span. Results 
pointed out that vaults have a relatively greater influence on the spatial stiffness of a structure than the roof truss. The last variant (Variant 4) assumed that roof truss and vaults were removed from the structure. In this variant the highest displacement values were obtained and in relation to variant 1 , they were greater by approximately $85 \%$. Result confirmed that the roof truss and vaults have a direct influence on the global stiffness of structure.

Table 2. Horizontal displacement of windward side wall.

\begin{tabular}{|c|c|c|c|c|}
\hline \multirow{2}{*}{ Measurement point } & \multicolumn{4}{|c|}{ Horizontal displacements [mm] } \\
\cline { 2 - 5 } & Variant 1 & Variant 2 & Variant 3 & Variant 4 \\
\hline $\mathbf{1}$ & 3.588 & 5.065 & 4.563 & 5.833 \\
\hline $\mathbf{2}$ & 5.558 & 9.460 & 6.642 & 10.098 \\
\hline $\mathbf{3}$ & 6.077 & 10.372 & 7.073 & 11.219 \\
\hline $\mathbf{4}$ & 5.257 & 8.247 & 6.422 & 9.807 \\
\hline $\mathbf{5}$ & 2.852 & 3.998 & 4.005 & 4.813 \\
\hline
\end{tabular}

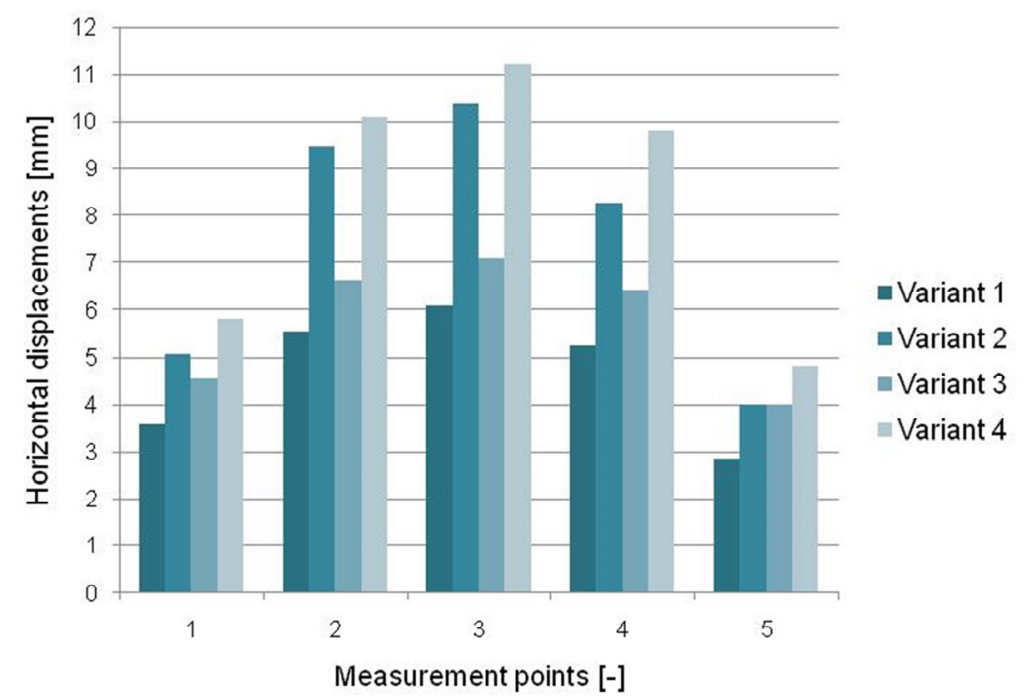

Fig. 5. Comparisson of horizontal displacements.

\section{Summary}

The article presents, on the example of a monumental neogothic church building, the issue of interaction between vaults and a roof truss with masonry walls. Comparison of horizontal displacement as an analysis result allowed determining the influence of the roof truss and vaults on building global stiffness. Both structural elements significantly reduce structure susceptibility for lateral loads. The roof truss structure has a smaller influence on the static work elimination (16\%) than vaults removal $(71 \%)$ in relation to the building structure with both systems cooperating with walls. The analysis of the structure without a roof truss and vaults showed a nearly $85 \%$ increase of displacements, confirming that occurrence of horizontal covering structures, which connect the load-bearing walls in monumental buildings is significant.

Badania zostały zrealizowane $\mathrm{w}$ ramach pracy $\mathrm{nr}$ S/WBiIŚ/1/2018 oraz nr MB/WBiIŚ/12/2017 i sfinansowane ze środków na naukę MNiSW. 


\section{References}

1. Roca P., Cervera M., Gariup G., Pela L., Arch Comput Methods Eng 17: 299-325 (2010)

2. Cakir F., Seker B. S., Dogangun A. Assessment of structural performance of historical Ishan church. Gradevinar 5/2014 (2014)

3. Betti M., Vignoli A., Constr. Build. Mater., 25 4308-4324 (2011)

4. Kawulok M. (Wzmocnienia tradycyjnych obiektów sakralnych podlegajacych wpływom eksploatacji górniczych. Budownictwo, czasopismo techniczne Politechniki Krakowskiej, Zeszyt 9, 2-B/2009, Kraków, 2009)

5. Balsamo A., Di Ludovico M., Lignola G. P., Prota A., Manfredi G., Cosenza E., (Wiley Encyclopedia of Composites, Chapter: Composites for Structural Strengthening. John Wiley \& Sons, Inc., Editors: L. Nicolais, A. Borzacchiello, 1-25 (2012)

6. Kamal O. A., Hamdy G. A., El-Salakawy T. S. (Nonlinear analysis of historic and contemporary vaulted masonry assemblages. Housing and Building National Research Center (HBRC) Journal 10, 235-246, 2014)

7. Romano A. (Modelling, analysis and testing of masonry structures. Doctoral thesis. Università degli Studi di Napoli Federico II Facoltà di Ingegneria, 2005)

8. Casarin F., (Structural assessment and seismic vulnerability analysis of a complex historical building. University of Terento, 2006)

9. Animas H., Navarro M., Pacheco-Martinez J., Garcia. J. L., Cordero T., Esparza C. J., Ortiz-Lozano J. A., (Structural analysis of the Temple of San Antonio in Aguascalientes, Mexico. SAHC2014-9th International Conference on Structural Analysis of Historical Constructions, Mexico , 2014)

10. Mola F., Vitaliani R. (Analysis, diagnosis and preservation of ancient monuments: The St. Mark's Basilica in Venice. Structural Analysis of Historical Constructions, International Center for Numerical Methods in Engineering (CIMNE), Barcelona 1996)

11. Silva B., Arede A., Guedes J. M., Costa A. (Assessment of the seismic behavior of Gondar Church using a continuum damage model. The 14th World Conference on Earthquake Engineering October 12-17, Beijing, 2008)

12. Cagnan Z. Numerical models for the seismic assessment of St. Nicholas Cathedral, Cyprus. Soil Dyn. Earthquake Eng., 39, 50-60 (2012)

13. Endo Y.. (Modelling and structural analysis of historical masonry systems including vaulted structure. Universitat Politecnica del Catalunya, Thesis Doctoral, Barcelona (2015)

14. Miedziałowski Cz., Orłowski Z., Chyży T., Orłowski M., Żakowicz A. (Ekspertyza budynku kościoła p.w. Wniebowzięcia NMP $w$ Biatymstoku $w$ związku z pękaniem sklepień. Politechnika Białostocka, Białystok, 2014)

15. Makarewicz z zespołem. (Inwentaryzacja i projekt budowlany remontu i przebudowy zabytkowego kościoła parafialnego p.w. Wniebowzięcia NMP w Białymstoku, Białystok, 2013-2014)

16. Jabłoński K. A., (Biały i czerwony: kościoły białostockiej parafii farnej. Wydawnictwo Buk, Białystok, 2008)

17. Lourenco P. B. (Computational strategies for masonry structures. Faculdade de Engenharia da Universidade do Porto, doctoral thesis, Porto (1996)

18. Lourenco P. B. (Experimental and numerical issues in the modeling of the mechanical behavior of masonry. Structural Analysis of Historical Constructions II. International Center for Numerical Methods in Engineering (CIMNE), Barcelona 1998) 
19. PN-EN 1996-1-1 Eurokod 6 (Projektowanie konstrukcji murowych. Część 1-1: Reguty ogólne dla zbrojonych i niezbrojonych konstrukcji murowych.)

20. PN-EN 1991-1-4:2008 Eurokod 1: Oddziaływania na konstrukcje. Część 1-4: Oddziaływania ogólne. Obciążenia wiatrem.

21. Li Q. S. i in., Eng. Struct. , 28 (2006) 1745-175 (2006)

22. Mamou M. i in., J. Wind Eng. Ind. Aerodyn. 96 793-806 (2008)

23. https://www.flickr.com/photos/mjlmryan/2801506236

24. http://www.studfiles.ru/html/2706/237/html_q2x2_WsUaz.xhsJ/htmlconvd-JuxD8G_

25. html_m6ce3a6eb.jpg 